\title{
Alexandre Dumas, Voyage en Russie
}

\section{Lise Sabourin}

\section{OpenEdition}

\section{Journals}

\section{Édition électronique}

URL : http://journals.openedition.org/studifrancesi/10004

DOI : 10.4000/studifrancesi. 10004

ISSN : 2427-5856

\section{Éditeur}

Rosenberg \& Sellier

\section{Édition imprimée}

Date de publication : 1 août 2017

Pagination : 377-378

ISSN : 0039-2944

\section{Référence électronique}

Lise Sabourin, «Alexandre Dumas, Voyage en Russie», Studi Francesi [En ligne], 182 (LXI | II) | 2017, mis en ligne le 01 août 2017, consulté le 09 janvier 2021. URL : http://journals.openedition.org/ studifrancesi/10004; DOI : https://doi.org/10.4000/studifrancesi.10004

Ce document a été généré automatiquement le 9 janvier 2021.

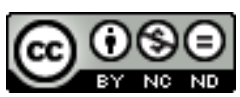

Studi Francesi è distribuita con Licenza Creative Commons Attribuzione - Non commerciale - Non opere derivate 4.0 Internazionale. 


\title{
Alexandre Dumas, Voyage en Russie
}

\author{
Lise Sabourin
}

\section{RÉFÉRENCE}

ALEXANDRE DUMAS, Voyage en Russie, préface de Michel Brix, Paris, Bartillat, 2015, 831 pp.

1 Vingt ans après Custine, Dumas père, en quête d'un second souffle après ses drames et ses romans, trouve dans la relation de son Voyage en Russie de quoi nourrir son journal le «Monte-Cristo» par quarante-trois chapitres «De Paris à Astrakan», parus du 15 juillet 1858 au 28 avril 1859.

2 Dans ses «explications préliminaires», il précise qu'en attendant de compléter son tour de Méditerranée par une traversée des îles grecques, il a accepté l'invitation des époux Kouchelef-Bezborodko rencontrés lors de leur joyeuse vie parisienne après leurs séjours à Rome, Naples et Florence. Il part donc avec eux en train, le 15 juin 1858, pour un voyage qui durera neuf mois, par Cologne, Berlin et Stettin, puis en bateau sur la Baltique par l'île de Gottland et Cronstadt jusqu'à Pétersbourg. C'est l'occasion de narrer bien des anecdotes sur la grande Catherine, sur son fils Paul I ${ }^{\mathrm{er}}$, sur Pierre le grand et sa favorite Catherine Menchikov, sa guerre avec Charles XII de Suède, sur Pouchkine le poète national russe que son métissage lui rend proche. L'observateur rend tout le pittoresque de ses visites à Peterhof, au fil de la Neva, puis à Moscou, avant de s'élancer sur la Volga en quête des mœurs autochtones à Nijni-Novgorod, Kasan, Saratov et Astrakan.

3 Sa continuation est dévolue à un autre titre, son Voyage au Caucase. Puis Dumas, installé en Italie, reprend sa narration pour «Le Constitutionnel», du 24 septembre au 6 décembre 1861, et de nouveau au «Monte-Cristo», du 28 mars au 29 août 1862, terminant la description des steppes et des lacs de Kalmoukie chez ces Tatars Kirghis qui l'avaient déjà fait rêver enfant lors de l'occupation de Paris par les troupes du Tsar en 1814.

4 Le tout est réuni chez Michel Lévy en quatre volumes publiés en 1865-1866 dans ce second temps de l'Empire libéral où le public est curieux du pays à qui Napoléon III a 
fait la guerre de Crimée, qu'une brève période d'ouverture - de 1855, par l'accession au trône d'Alexandre II, à 1863, avec la répression de l'insurrection polonaise - a rendu accessible à Dumas.

5 Sur le ton oral de la causerie, il laisse courir sa plume, en brefs paragraphes, parfois d'une seule phrase en quelques lignes, avec son allègre curiosité. Grâce à la large pratique de la langue française chez les élites russes, il peut savourer à son aise la rencontre des multiples lecteurs de ses romans et de spectateurs de ses pièces, jouées souvent dans l'année de leur création. Son tempérament, finalement assez proche de l'exubérance slave, lui permet de présenter ses aventures sous le signe de la fête et de la jouissance, même si parfois il constate avec chagrin la résignation du peuple russe. Mais rien ne saurait contenir son allant naturel et il narre avec la verve des Trois Mousquetaires les dessous de l'histoire de Romanov ou les souvenirs de la Moskowa.

Dans cette édition grand public, sans note ni bibliographie, Michel Brix ne peut que préfacer (pp. 7-16) et signaler l'existence d'autres écrits complémentaires, des notes incluses dans les Impressions de voyage, des lettres, des extraits d'Album amicorum de Jenny Falcon et des articles parus dans le magazine «Le Tour du monde», déjà publiés par ailleurs. 